\title{
EXTENDING AND MAINTAINING THE IN VITRO COLLECTION OF (INTER)NATIONAL HOP VARIETIES IN UKRAINE
}

\author{
V. B. Kovalev 1,", T. I. Kozlik ${ }^{2}$, L. V. Protsenko ${ }^{3}$, A. V. Bober ${ }^{4}$, Б. F. Kormiltsev ${ }^{5}$ \\ ${ }^{1}$ Zhytomyr National Agroecological University, 7, Staryi blvd, Zhytomyr, Ukraine, 10008 \\ ${ }^{2,3,4}$ Institute of Agriculture of Polissia of NAAS, 131, Kyivske shosse, Zhytomyr, Ukraine, 10007 \\ ${ }^{5}$ National University of Life and Environmental Sciences of Ukraine, 15, Heroyiv Oborony Str, Kyiv, Ukraine, 03041
}

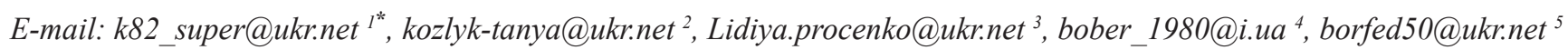

Received January 12, 2020 / Received November 03, 2020 / Accepted November 20, 2020

\begin{abstract}
Despite the decline in the national hop production, a part of hop products, made of Ukrainian aroma hop, is highly estimated in the international market and exported. Therefore, a relevant prerequisite of ensuring a sufficient level of competitiveness of domestic hop production is the expansion of its assortment. To satisfy this need the breeders face the task of creating varieties with unique characteristics, which requires searching for new forms and strains of hop with increased content of different biologically active compounds in cones. In this regard national research program aimed to investigate genetic stability of hop varieties during multiple planting and storing of explants in in vitro conditions while introducing them into the collection, adapting the composition of Murashige and Skoog culture medium for specific varieties is discussed. Studies conducted included the analysis of plants by morphological and variety-specific traits, the identification of varieties by biochemical criteria, improvement of hop regenerants using ELISA, molecular-genetic analysis based on PCR (polymerase chain reaction) for identification of hop genotypes and determination of genetic stability, and the improvement of method of microclonal reproduction of hop. As a result of the perennial research of cultivating hop planting material using the Murashige and Skoog complex of nutrients, the foundations of creating and maintaining the in vitro collection of hop varieties were first elaborated in Ukraine which allow for the possibility of decreasing the concentration of nutrients in the culture medium by $50 \%$, replacing expensive gel-forming preparation for the maintenance of plants in the culture medium - agar-agar, the share of whose cost in the medium composition is up to $70 \%$, with a cheaper substance - modified starch DDKamod or agroperlite, and reducing the expenses for the maintenance of genetic pool in the in vitro collection. It was determined that the spectra of microsatellite loci of the amplified DNA of the explants, cultivated in vitro, during the study period did not differ from the spectra of plant DNA prior to cloning, which demonstrated DNA stability and allowed cultivating hop varieties in the in vitro culture without any changes in the genome. The composition of media for cultivation and longterm storing of hop varieties in in vitro conditions was selected.
\end{abstract}

Key words: hop, varieties, identification, genotypes, in vitro collection, culture medium.

DOI: https://doi.org/10.15407/agrisp7.03.061

Unique organic substances - bitter principles, essential oils and polyphenols - are synthesized in hop cones (Humulus lupulus L.), due to which hop is widely used in different branches of industry. Up to $90 \%$ of hop produce is used in beer production, which is in great demand among consumers, and $10 \%$ go to perfumery, pharmaceutical, bread-baking, and alcohol production.

Ukraine's brewing industry requires about 120 $155 \mathrm{t}$ of alpha-acids annually, only $20 \%$ of which are

(C) V. B. KOVALEV, T. I. KOZLIK, L. V. PROTSENKO, A. V. BOBER, Б. F. KORMILTSEV, 2020 supplied by the domestic production, and the rest are imported hop products.

The experience of hop-producing farms has demonstrated that hop production is a source of considerable financial income, amounting up to $50 \%$ in the structure of plant cultivation produce, with over $90 \%$ for the specialized farms.

In the past, Ukraine supplied $70 \%$ of raw hop produce for the entire former Soviet Union. Besides, till 1991, over 4,000 t of hop were exported to other countries.

The decline in hop production, registered in Ukraine since 1990, was triggered by serious disorganizing fac- 
tors: antialcohol campaign (1985), Chernobyl catastrophe (1986), the dissolution of the USSR (1991), aggressive strategy of foreign producers and ousting of Ukrainian hop producers from both domestic and international markets, using dumping prices (1996-1997), and lack of experience in the issues of strategy and tactics of competition, etc.

Hop production of Ukraine lost its position regardless of globally acknowledged high quality of Ukrainian hop. In the last 29 years, the area of hop production in Ukraine decreased from 7.4 thousand ha in 1990 down to 0.4 thousand ha, i.e. 18.5 times. In 2008-2019, the number of active farms decreased 3.1 times.

The leading hop production area is the Zhytomyr region $-74.1 \%$ of the total area, the rest of hop fields are located in Lviv region - $15.4 \%$, Khmelnytskyi region $-8.0 \%$, and Rivne region $-2.5 \%$.

In recent years, the specialists deem the functioning of hop industry in Ukraine to be critical. Large brewing companies with foreign capital, keeping their current monopoly in the market, have restricted the use of Ukrainian hop produce due to their own interest in supplying and using hop products from abroad. At the same time, the quality of Ukrainian hop is not inferior to that of foreign produce, which is especially true for the most delicate aroma varieties of hop, as agroclimatic conditions of Ukrainian Polissia meet the requirements to cultivating this kind of hop, traditionally in demand by the market, in the best possible way (Protsenko L and Litvynchuk S, 2015). Aroma varieties in the structure of hop fields of Ukraine take $84 \%$, bitter ones $-16 \%$, and their variety assortment is similar to analogues of the leading European countries. Even despite the decline in the production volumes, a part of hop products, made of Ukrainian aroma hop, is highly estimated in the international market and exported.

Therefore, a relevant prerequisite of ensuring a sufficient level of competitiveness of domestic hop production is the expansion of its assortment.

A total of 16 hop varieties are currently cultivated in Ukraine, including the ones of foreign selection Newport and Magnum. The breeders face the task of creating varieties with unique characteristics, which requires searching for new forms and strains of hop with increased content of different biologically active compounds in cones (Kovalev V et al, 2015; Dresel M et al, 2016).

To direct the breeding studies, it is relevant to have thorough selection of paternal pairs which is possible on condition of preserving the gene pool of hop and genotyping of the initial breeding material. At the same time, the perspectives of hop production development are greatly dependent on the organization of the nursery garden, which should envisage organized distribution of highly productive hop varieties and providing the farms with planting material that ensures high productivity, purity of the variety and helps treating plants from viral diseases (Melnichuk. The creation of new hop varieties and their introduction into production should be based on the preservation of its gene pool which becomes of greater relevance each year.

In vitro methods may make their valuable contribution to each stage of the hop breeding and planting process. The application of clonal microreproduction allows shortening the time of reproducing new varieties 4-5x in comparison with traditional methods. The advantages of microreproduction lie in the small amount of the initial material and minimal laboratory area which is sufficient to ensure a high reproduction coefficient. Clonal microreproduciton is also a component of integral protection of hop fields. In addition, molecular tests for viral pathogens and concomitant thermotherapy stimulate and ensure the program of cultivating certified planting material and are in agreement with the doctrine of ecologization of modern agricultural production (Kunitake H et al, 1995; Hataya T et al, 2001; Gergerich R et al, 2015; Trojak-Goluch A et al, 2015).

The most reliable method of improving hop planting material is microcultivation of the improved plants in the in vitro culture. The improved planting material is the initial foundation for creation of graft plantings and the transition of hop production to the elite foundation, which will ensure longer use of hop fields and enhance their productivity by $30-40 \%$. Therefore, the creation of the in vitro collection of the best genotypes of global gene pool of hop is a relevant component of obtaining new, healthy initial planting material.

The Institute of Agriculture of Polissia, NAAS, has a global field collection of 240 varieties and strains of hop. The maintenance of this collection requires extensive economic and industrial expenses. Deteriorating ecologic and geophysical factors, higher anthropogenic burden, and insufficient financing for collection maintenance increase the threat of irreversible loss of valuable varieties and strains of hop. Thus, the in vitro collection should replace the field one. The in vitro collection of the Institute of Agriculture of Polissia, NAAS, consists of 56 hop genotypes, and is constantly replenished and expanded. The use of the in vitro collection allows sav- 
ing about UAH 100 thousand per year, previously spent on maintaining and renewing the collection nursery.

The maintenance of the in vitro collection requires detailed improvement, it did not till now envisage the monitoring of viability of microplants. Improvement is also needed for the methods of estimating genetic stability of in vitro plants, determining the terms of preserving plants in culture without their re-planting, and defining the composition of culture media. There are several ways of keeping plants in vitro, one of them is the deposition of plants under low positive temperatures. Such conditions of preserving plants in vitro may be stressful for them, which will trigger corresponding reactions in the plant organism with the accumulation of reactive oxygen intermediates (ROI) in cells, and the accumulation of ROI may result in internal changes in macromolecules, including DNA disorders. In case of multiple planting of explants, some plants may have mutations even in the generation of regenerated plants. This phenomenon, called somaclonal or genetic variability, may be inherited not only in a number of cell generations but also in the generation of regenerants. Therefore, a mandatory prerequisite of microclonal reproduction of plants is the use of plant parts with strong genetic stability during all the stages of the process from explants to plants in the field. For common hop, these conditions are mainly satisfied by the use of apexes and auxiliary buds (Kormiltsev B et al, 2008).

During the long period of multiple passaging or storing explants in the in vitro collection, the most urgent problem, requiring a scientific solution, is monitoring of varietal purity.

Genetic stability is determined by the methods of identifying hop genotypes by morphological, biochemical, economic and, since the last 20 years, also molecular traits (Kovalev V et al, 2015; Sivolap Yu et al, 2010; Melnichuk M et al, 2008; Brady J et al, 1996; Jakse J et al, 2004; Cerenak A et al, 2004).

The studies in Czech Republic, Germany, the USA, Slovenia, Japan, New Zealand [12-18] and in Ukraine (Institute of Agriculture of Polissia, NAAS, National University of Life and Environmental Sciences of Ukraine, the Selection and Genetics Institute - the National Center of Seed and Cultivar Investigation) (Kovalev V et al, 2015; Sivolap Yu et al, 2010; Melnichuk $\mathrm{M}$ et al, 2008) proved the reasonability of molecular analysis for identification of varieties of Ukrainian and global collections of common hop diversity. The results of studies on molecular-genetic polymorphism of hop genome and DNA-markers, elaborated on their basis, are introduced into the breeding of this crop for identification of varieties and new breeding material, control of genetic purity of varieties, determination of somaclonal variability and genetic stability, genetic mapping, detection and diagnostics of pathogens. Different types of molecular markers are used, including RAPD - (Random Amplified Polymorphic DNA), SSR - (Simple Sequence Repeats), STS - (Sequence Tagged Sites), ISSR - (Inter-Simple Sequence Repeat), AFLP - (Amplified Fragment Lengths Polymorphism), SNP-markers (Single Nucleotide Polymorphisms).

The most suitable markers for assessment of genetic diversity of hop include microsatellite (MS) or SSR-markers with high degree of polymorphism, codominant character of inheritance, high reproduction of results, the possibility of standardizing a set of markers and methods among laboratories (Kovalev V et al, 2015; Sivolap Yu et al, 2010; Melnichuk M et al, 2008; Brady J et al, 1996; Jakse J et al, 2004; Cerenak A et al, 2004; Henning J et al, 2015; Beatson R et al, 2016; Patzak J et al, 2008).

Till 2005, the number of MS markers of common hop was limited: the first four SSR-markers were developed by Brady J.I. in 1996 (Brady J et al, 1996). In 2002 Jakse J. suggested 11 (Jakse J et al, 2004), in 2004 Hadonou A. suggested 10 new markers (Cerenak A et al, 2004), and in 2008 - 60 markers (Stajner N et al, 2008).

The polymorphism of SSR-markers of hop varieties bred in Ukraine was investigated before (Kovalev V et al, 2015; Sivolap Yu et al, 2010; Melnichuk M et al, 2008). It has been determined that each genotype of Ukrainian hop variety has an individual set of alleles of investigated loci.

While using biotechnologies in vitro on the industrial scale, it is important to decrease their cost of production and increase economic efficiency. The highest expenses proved to be the gel-forming component in culture media - agar-agar, whose cost in the composition of the media is up to $70 \%$. Therefore, the replacement of this preparation with a cheaper one would decrease the cost of production for the biotechnology of hop reproduction considerably. Recently different forms of modified starch, including DDKamod, have been suggested as an alternative to agar-agar. The scientific references demonstrated that the use of DDKamod improved plant regeneration considerably during microclonal reproduction of some vegetables, stimulated the formation of androgenous structures and regenerant plants in the culture of anthers in vitro of spring barley (Bilinska O, 2009). Another way of reducing the cost 
of hop planting material is the replacement of agar-agar with perlite in the culture medium.

To meet these goals national research program was established to investigate genetic stability of hop varieties during multiple planting and storing of explants in in vitro conditions while introducing them into the collection, adapting the composition of Murashige and Skoog culture medium for specific varieties.

The studies were conducted in 2011-2019, in the laboratory of biotechnology, the Department of breeding and innovation technologies and the Department of biochemistry of hop and beer and biotechnology, the Institute of Agriculture of Polissia, NAAS. The samples for studies were selected by morphological and varietyspecific traits in the breeding nursery plantation. The selected donor plants were identified in the laboratory of biochemistry of hop and beer according to varietal biochemical characteristics. Planting material, isolated from donor plants (grafts), was planted into perlite and cultivated in the growth chamber. Prior to microclonal reproduction, the initial material was improved. The obtained regenerants passed thermotherapy (Melnichuk M et al, 2000; Adams A, 1975) and further rooting in conditions in vitro.

The cultivation of regenerants was completed in the growth chamber, at $22-26{ }^{\circ} \mathrm{C}$, relative humidity of $65-75 \%$, illumination of 2.5 kilolux with the photoperiod of $16 \mathrm{~h}$. After the formation of four-five pairs of leaves on the regenerants, sick plants were removed. The improved plants were checked for diseases and transferred for microclonal reproduction in sterile chambers. Micropods were planted in the Murashige and Skoog culture medium, modified by Kalinin FL (Kalinin F et al, 1980) with our modifications for hop. The composition of Murashige and Skoog culture medium was adapted to hop plants - $200 \mathrm{mg} / \mathrm{l}$ ammonium nitrate, $6 \mathrm{mg} / 1 \mathrm{~B}$ IAA and $1 \mathrm{mg} / 1 \mathrm{IBA}$ were additionally introduced. After the regenerants formed 5-6 nodes, they were grafted again, and the regeneration process was repeated.

The scheme of experiments included the following medium variants: standard - Murashige and Skoog culture medium as control, and media with changed content of auxins, kinetin, micro- and macroelements (A - macroelements 1/2 M.S., $\beta$-IAA - $12 \mathrm{mg} / \mathrm{l} ; \mathrm{A}_{1}-$ microelements $1 / 2$ M.S., $\beta$-IAA - $6 \mathrm{mg} / \mathrm{l} ; \mathrm{A}_{2}-$ macroelements $1 / 2$ M.S., $\beta$-IAA - $6 \mathrm{mg} / \mathrm{l}$, IBA - $1 \mathrm{mg} / \mathrm{l}$; $\mathrm{A}_{3}-$ macroelements $1 / 2$ M.S., $\beta$-IAA $-6 \mathrm{mg} / \mathrm{l}$, kinetin $0.5 \mathrm{mg} / 1 ; \mathrm{A}_{4}-$ macroelements $1 / 2$ M.S. $\left(\mathrm{NH}_{4} \mathrm{NO}_{3}-\right.$ $200 \mathrm{mg} / \mathrm{l}), \beta$-IAA - $6 \mathrm{mg} / \mathrm{l})$.

The impact of concentration of nutrients in the culture medium on the regeneration of Zagrava hop explants of the in vitro culture was studied according to the common methods, approved at the Institute of Agriculture of Polissia, NAAS, and the regulatory documents in force. The study was conducted using the methodological approaches, used in the international practice, for instance, specified in the work of Kalinin FL (Kalinin F et al, 1980).

The study of the genome of hop varieties, whose characterization is presented in Table 1, was conducted using biotechnological methods of determining varietal polymorphism of hop DNA.

The plants were selected by notable varietal, morphological and biochemical traits from the basic collection of common hop gene pool, held at the Institute of Agriculture of Polissia, NAAS. The leaves for analysis were collected from the identified hop plants and regenerants in vitro, which were obtained from the initial plants as well as from the plants, already kept in the in vitro collection.

The grafts were planted into the mixture of peat and sand and germinated at $+20{ }^{\circ} \mathrm{C}$ and illumination of 2 kilolux. After the grafts formed green sprouts with five-

Table 1. The characterization of hop varieties under investigation

\begin{tabular}{|c|c|c|}
\hline Variety & Genealogy of variety & Economic characterization \\
\hline Slovianka & $\begin{array}{l}\text { Aroma female plant (Ukraine)/male form } \mathrm{I}_{2} \text { of variety } \\
\text { F-108 (Great Britain) }\end{array}$ & $\begin{array}{l}\text { Fine aroma mid-season variety, yield }-1.5-2.7 \mathrm{t} / \mathrm{ha} \text {, } \\
\text { Content of alpha-acids } 4.5-5.5 \%\end{array}$ \\
\hline Zagrava & $\begin{array}{l}\text { Aroma female plant (Ukraine)/male form } \mathrm{I}_{2} \text { of variety } \\
\text { F-108 (Great Britain) }\end{array}$ & $\begin{array}{l}\text { Aroma mid-season variety, yield }-1.9-2.8 \mathrm{t} / \mathrm{ha} \\
\text { content of alpha-acids } 5.4-8.5 \%\end{array}$ \\
\hline Kumyr & $\begin{array}{l}\mathrm{F}_{4} \text { of the variety Clone- } 72 \text { (Czech Republic)/male plant } \\
\text { from Colorado (USA) }\end{array}$ & $\begin{array}{l}\text { Bitter mid-season variety, yield }-1.6-2.8 \mathrm{t} / \mathrm{ha} \\
\text { content of alpha-acids } 11.0-14.5 \%\end{array}$ \\
\hline Alta & Variety Bullion (Great Britain)/open pollination & $\begin{array}{l}\text { Bitter early-season variety, yield }-1.3-2.4 \mathrm{t} / \mathrm{ha} \text {, } \\
\text { content of alpha-acids } 10.5-13.5 \%\end{array}$ \\
\hline
\end{tabular}


six internodes, their tops were removed, sterilized in $3 \%$ solution of chloramin and planted onto agarized culture media, containing macro- and microelements, glucose, kinetin, and $\beta$-IAA, and not containing mutagenic factors. After the regeneration of micrografts, the plants were grafted, and the process was repeated. Each following passage was done two months later. The subcultivation of explants was conducted for a year. DNA analysis was conducted to determine genome stability of regenerants during the process of their cultivation in the in vitro conditions. The samples for the analysis were isolated after half a year and a year. In addition, the plants of the abovementioned varieties, cultivated for two and more years, with the presumably possible DNA changes, were also selected from the in vitro collection.

The determination of varietal DNA polymorphism by selected SSR markers was done in at least 3 repeats by the method of the Southern Biotechnological Center of NAAS [10] with some modifications.

DNA isolation was done via proteolysis with proteinase $\mathrm{K}$ in the presence of SDS (sodium dodecylsulfate) and CTAB (cetyl trimethyl ammonium bromide). Additional maceration was conducted in the solutions of driselase, pectinase or cellulase (Sigma-Aldrich Chemie, Germany) in the concentration of $10-20 \mathrm{mg} / \mathrm{ml}$, $0.4 \mathrm{M}$ mannitol, at $28^{\circ} \mathrm{C}$ for $8-16 \mathrm{~h}$. DNA purification was conducted on Millipore columns with the set of Qiagen buffers according to the manufacturer's instructions. DNA amplification was conducted on GeneAmp PCR9700 amplifier. The study of SSR loci involved 11 pairs of primers. The sequences of primers and PCR conditions are presented in Table 2. DNA-marker of the molecular weight, M50bp (100-1,500 bp), of Primetech International, USA was used as control.

The electrophoresis was conducted in horizontal $2 \%$ agarose gels, in $1 \mathrm{x}$ TBE-buffer $(89 \mathrm{mM}$ tris- $\mathrm{HCl} \mathrm{pH}$ $8.2,89 \mathrm{mM}$ boric acid, $2 \mathrm{mM} \mathrm{Na}_{3}$ EDTA) at the voltage of $75 \mathrm{~V}$ for $2 \mathrm{~h}$.

The visualization of DNA bands in agarose gel and photographing were conducted in the documentation and analysis system for gels, GelVue UV Transilluminator, Syngene, USA, according to the manual. The determination of genetic distances according to SM coefficient based on the data of the electrophoretic distribution of amplification products was performed using TREE 4.0.

The studies on introduction and cultivation in the in vitro collection of hop varieties were conducted using 7 varieties from Great Britain: East Kent Holding,
Nordgaard, Target, WGV, Northern Brewer, OZ-79 and OR-55. The selection of the best hop plants involved the investigation of the collection plants of the mentioned varieties by such major morphological traits, as a form of the bush, length of side branches, stem color, form, aroma, and density of cones. The plants, inferior by one of the abovementioned indices, were removed. The remaining plants were subjected to positive selection by quality traits - they were not to have the signs of disease and were noted for high productivity.

The cones from these plants underwent biochemical analysis for the determination of the main varietal biochemical traits: the ratio between beta-acids and alphaacids, which is a constant for each variety, the amount of cohumulone in the composition of alpha-acids and the amount of colupulone in the composition of beta-acids. The composition of essential oils is a relevant varietal trait of hop. In case of a small amount of myrcene in the composition of the essential oil, aroma varieties have a high amount of farnesene, whereas the latter is almost absent in bitter varieties, but they have much humulene or post-humulene acids. Most traditional British variet-

Table 2. The sequences of primers and PCR conditions

\begin{tabular}{|c|c|c|c|}
\hline 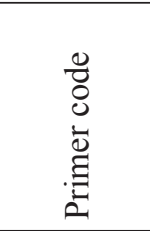 & Sequence of primers & 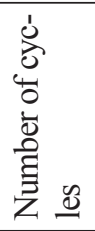 & 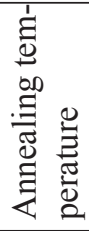 \\
\hline $11 a-59$ & $\begin{array}{l}\text { F gettcaaccctctaatttctgacc } \\
\mathrm{R} \text { agaagggacactcggttaatcc }\end{array}$ & 27 & $55^{\circ}$ \\
\hline $3 a-88$ & $\begin{array}{l}\text { F taggccetactctagctcgccaga } \\
\text { R cctggttgtgtaggggcttggac }\end{array}$ & 27 & $55^{\circ}$ \\
\hline $5-2$ & $\begin{array}{l}\text { F tcgaatggtcctagatatcccc } \\
\mathrm{R} \text { cagtaaatggatgcttgaaggc }\end{array}$ & 27 & $55^{\circ}$ \\
\hline $7 a-82$ & $\begin{array}{l}\text { F gtggaggcgacggtgtagaggaa } \\
\text { R tcaaaattcctcaactgcgcttaa }\end{array}$ & 27 & $55^{\circ}$ \\
\hline HlG-A3 & $\begin{array}{l}\text { F tttcaccaaatttccaagtgc } \\
\text { R ggtgccaagggatagacat }\end{array}$ & 27 & $57^{\circ}$ \\
\hline HlG-A4 & $\begin{array}{l}\text { F ccaacactagggtttgcatc } \\
\text { R aggctcatcccagaagtatg }\end{array}$ & 28 & $55^{\circ}$ \\
\hline HlG-A9 & $\begin{array}{l}\text { F caaactaggaacagagtcaagt } \\
\text { R ccaacgtaaagcaaccaac }\end{array}$ & 27 & $56^{\circ}$ \\
\hline H1G-A29 & $\begin{array}{l}\text { F tccetctcattttttcacacc } \\
R \text { tcggggtcgataatggtta }\end{array}$ & 28 & $56^{\circ}$ \\
\hline HlG-T2 & $\begin{array}{l}\text { F gtccttcgagcaaaccttata } \\
\text { R tcacccettatgcccaatt }\end{array}$ & 27 & $56^{\circ}$ \\
\hline HIG-T4 & $\begin{array}{l}\text { F tggtagttattttgattctgtgc } \\
\text { R gcaatattatcagaagcagaagc }\end{array}$ & 27 & $56^{\circ}$ \\
\hline HlG-T5 & $\begin{array}{l}\mathrm{F} \text { atacccetcctgttttctacc } \\
\mathrm{R} \text { cgtcgggttccaaaggatt }\end{array}$ & 28 & $58^{\circ}$ \\
\hline
\end{tabular}


ies are bitter. All the selected varieties corresponded to varietal passport data.

After the introduction to the in vitro collection we selected the plants, which corresponded to the passport data of the variety by all the morphological and biochemical features in the best possible way and were notable for high indices of productivity and content of alpha-acids.

The variety Northern Brewer was bred in England, it has high content of alpha-acids. Target is a variety with high content of bitter substances and aroma of medium intensity. East Kent Holding is a tender aroma variety; it is considered to be the variety with the most typical English aroma and better taste. WGV is the most famous English hop variety. Other hop varieties and strains of English selection were obtained from the above-characterized varieties.

Two-node grafts with four buds were cut out from the underground part of the selected plants for the studies. The plants were treated with thermotherapy for 10 days at $35-37^{\circ} \mathrm{C}$, then checked by ELISA for a viral infection, sterilized and introduced into the culture in vitro.

The results of the studies on the impact of the concentration of nutrients in the cultivation medium for hop plant culture in vitro confirmed the possibility of decreasing the cost of the technology of cultivating regenerants.

While analyzing the results of the survival rate for Zagrava variety plants, no suppression of the survival rate was noted for Zagrava hop explants after the decrease in the concentration of nutrients in the culture medium by $50 \%$ (Table 3 ). The indices of plant growth the number and length of roots, height and weight of plants - practically did not change.

Further lowering the nutrient concentration down to $25 \%$ resulted in reduction of all technological characteristics, especially the survival rate which should be considered while using the culture medium with the decreased concentration of nutrients. In our experiments this reduction was $5 \%$.

Table 3. The development and survival rate of Zagrava hop explants at different concentrations of the culture medium (the average for 2017-2019)

\begin{tabular}{l|c|c|c|c|c|c|c|c|c|c}
\hline \multirow{2}{*}{ Concentration of culture medium } & \multicolumn{2}{|c|}{$\begin{array}{c}\text { Number } \\
\text { of roots }\end{array}$} & \multicolumn{2}{|c|}{ Root length } & \multicolumn{2}{c|}{$\begin{array}{c}\text { Height of } \\
\text { plants }\end{array}$} & \multicolumn{2}{|c|}{$\begin{array}{c}\text { Weight of } \\
\text { plants }\end{array}$} & \multicolumn{2}{c}{$\begin{array}{c}\text { Survival } \\
\text { rate }\end{array}$} \\
\cline { 2 - 12 } & it. & $\mathrm{x} \pm \mathrm{SD}$ & $\mathrm{cm}$ & $\mathrm{x} \pm \mathrm{SD}$ & $\mathrm{cm}$ & $\mathrm{x} \pm \mathrm{SD}$ & $\mathrm{cm}$ & $\mathrm{x} \pm \mathrm{SD}$ & $\%$ & $\%$ \\
\hline $100 \%$ concentration of culture medium (control) & 3.4 & 0.28 & 2.7 & 0.25 & 3.9 & 0.33 & 0.118 & 0.02 & 97 & 100 \\
$75 \%$ concentration of culture medium & 3.4 & 0.28 & 2.7 & 0.25 & 5.3 & 0.47 & 0.121 & 0.02 & 98 & 101 \\
$50 \%$ concentration of culture medium & 3.3 & 0.27 & 2.9 & 0.26 & 5.0 & 0.45 & 0.116 & 0.02 & 97 & 100 \\
$25 \%$ concentration of culture medium & 3.2 & 0.26 & 2.3 & 0.21 & 4.8 & 0.41 & 0.115 & 0.02 & 92 & 95 \\
\hline
\end{tabular}

Table 4. The development and survival rate of hop explants while cultivating in the culture medium with agroperlite (the average for 2016-2019)

\begin{tabular}{|c|c|c|c|c|c|c|c|c|c|c|}
\hline \multirow{2}{*}{ Experiment variant } & \multicolumn{2}{|c|}{$\begin{array}{l}\text { Number } \\
\text { of roots }\end{array}$} & \multicolumn{2}{|c|}{ Length of roots } & \multicolumn{2}{|c|}{$\begin{array}{l}\text { Height of } \\
\text { plants }\end{array}$} & \multicolumn{2}{|c|}{$\begin{array}{l}\text { Weight of } \\
\text { plants }\end{array}$} & \multicolumn{2}{|c|}{$\begin{array}{l}\text { Survival rate of } \\
\text { plants }\end{array}$} \\
\hline & it. & $\%$ & $\mathrm{~cm}$ & $\%$ & $\mathrm{~cm}$ & $\%$ & g & $\%$ & $\%$ & $\%$ \\
\hline \multicolumn{11}{|c|}{ Alta } \\
\hline Agar-agar (control) & 3.5 & 100 & 1.6 & 100 & 5.2 & 100 & 0.134 & 100 & 96 & 100 \\
\hline Агроперліт & 4.2 & 120 & 1.9 & 119 & 4.8 & 92 & 0.128 & 96 & 88 & 92 \\
\hline $\mathrm{LSD}_{05}$ & \multicolumn{2}{|c|}{0.32} & \multicolumn{2}{|c|}{0.28} & \multicolumn{2}{|c|}{0.24} & \multicolumn{2}{|c|}{0.3} & \multicolumn{2}{|c|}{2.2} \\
\hline \multicolumn{11}{|c|}{ Zagrava } \\
\hline Agar-agar (control) & 3.8 & 100 & 2.1 & 100 & 4.5 & 100 & 0.149 & 100 & 98 & 100 \\
\hline Agroperlite & 4.4 & 116 & 2.3 & 110 & 3.9 & 87 & 0.142 & 95 & 95 & 97 \\
\hline $\mathrm{LSD}_{05}$ & \multicolumn{2}{|c|}{0.25} & \multicolumn{2}{|c|}{0.36} & \multicolumn{2}{|c|}{0.18} & \multicolumn{2}{|c|}{0.32} & \multicolumn{2}{|c|}{2.4} \\
\hline
\end{tabular}


We also studied the replacement of agar-agar in the culture medium with modified starch DDKamod. The results turned out to be positive - the concentration of $100 \mathrm{mg}$ DDKamod per 11 of the culture medium ensured the fixation of micrografts in the medium and their survival rate on the level of agar-agar which allowed using it for microclonal reproduction of hop. The application of higher concentrations led to the formation of rather dense media which complicated the process of planting micrografts. The medium with the concentration of DDKamod of $80 \mathrm{mg} / 1$ did not ensure the required density, it was found to be rather liquid which did not allow for the fixation of micropods in the medium and made it unsuitable for the technology of microclonal reproduction. In 2015-2018 DDKamod passed the check on different varieties of hop. No delay in the development of explants in the media with DDKamod was noted for early-season hop varieties, and the delay on the early stages of the development of late-season varieties was compensated with more active development in the following period. Based on the data obtained, in 2018 DDKamod was recommended for wide application in the technology of reproducing hop by the in vitro method.

Another way of reducing the cost of cultivating hop planting material in vitro was the replacement of agaragar with agroperlite in the culture medium, which demonstrated positive results. The investigation in 2016-2019 were targeted on using agroperlite in the technology of cultivating hop planting material and storing explants in the in vitro collection.

One of the main and relevant factors in the development of microplants, their survival rate and growth is the root system - the number of the roots formed and their length. The studies on the explants of Zagrava and Alta varieties demonstrated that the replacement of agar-agar in the culture medium with agroperlite promoted the increase in the number of roots by $16-$ $20 \%$ and the length of the roots by $10-19 \%$ respectively. However, the explants of Alta hop variety slightly lagged behind in their growth, thus, their weight was $4 \%$ smaller compared to the control plants with the reduction in the survival rate down to $8 \%$.

During the cultivation of micropods of Zagrava variety, there could be some deviations in the height, growth, and development (weight) of the grafts. However, at the final stage, the survival rate of explants was rather high which served as a basis for possible use of agroperlite instead of agar-agar in culture media to reproduce hop varieties in vitro and maintain the plants in the collection with the consideration of their varietal specificities.

The studies of molecular-genetic variability of hop varieties during their long-term subcultivation in the in vitro culture in the media, not containing mutagens, have been under way since 2010. It was determined that the spectra of amplified DNA of the explants, cultivated in vitro for half a year, a year and two years did not differ from DNA spectra of the donor plants, obtained prior to cloning. The photos of the electrophoretic profiles of PCR analysis products for 4 hop varieties were presented in the article (Shtanko IP et al, 2016).

The results of the study on the introduction of British varieties into the in vitro collection demonstrated that the most successful regeneration of explants was registered for such varieties as Northern Brewer, Nordgaard, Target, and OZ-79, whereas the regeneration of OR-55 explants was below $50 \%$ almost in all variants of the investigated media, except the medium A4 for which there was regeneration of $67 \%$ micrografts (Table 5).

As seen from Table 5, most English varieties had the most successful regeneration on the medium with $200 \mathrm{mg} / \mathrm{l}$ of ammonium nitrate and $6 \mathrm{mg} / \mathrm{l} \mathrm{B}-\mathrm{IAA},\left(\mathrm{A}_{4}\right)$ except for OZ-79, whose regeneration was more successful in the medium, introduced $1 / 2$ of microelements according to M.S. and $\beta$-IAA - $12 \mathrm{mg} / \mathrm{l}$ (A) and Nordgaard, where $100 \%$ regeneration was observed in the medium, introduced $\beta$-IAA $-6 \mathrm{mg} / 1$ and IBA $-1 \mathrm{mg} / 1$ $\left(\mathrm{A}_{2}\right)$. These data were published in the article ( Kozlyk TI et al, 2017).

Table 6 presents the main varietal biochemical indices, obtained while analyzing the cones of plants, introduced into the in vitro collection of varieties.

The scientific institutions of many countries transferred the reproduction of different species of plants and their varieties from in vivo conditions into the laboratory conditions in vitro. It involves the use of previously elaborated culture media (Kalinin F et al, 1980) and stimulators of regeneration, growth, and survival of plants in open soil (Bairu M et al, 2006; Debergh $\mathrm{P}$ and Read P, 1990) the culture of meristem tissues, thermotherapy, and chemotherapy (Adams A, 1975; Spiegel S et al, 1995; Trojak-Goluch A et al, 2015; Liberatore $\mathrm{C}$ et al, 2018).

Obtaining many explants from one initial plant may be accompanied with the probability of somaclonal variations which may result from somatic mutations of the donor plant (Kunitake $\mathrm{H}$ et al, 1995). 
KOVALEV et al.

Table 5. The impact of the media composition on the regeneration of hop varieties, selected in Great Britain, in culture in vitro

\begin{tabular}{|c|c|c|c|c|c|}
\hline \multirow{2}{*}{ Varieties } & \multicolumn{5}{|c|}{ Percentage of regeneration on different media $(\%)$} \\
\hline & A & $\mathrm{A}_{1}$ & $\mathrm{~A}_{2}$ & $\mathrm{~A}_{3}$ & $\mathrm{~A}_{4}$ \\
\hline Northern Brewer & 46 & 67 & 53 & 71 & 99 \\
\hline Nordgaard & 77 & 72 & 100 & 69 & 57 \\
\hline East Kent Holding & 64 & 71 & 53 & 89 & 96 \\
\hline Target & 68 & 96 & 66 & 72 & 100 \\
\hline 'OZ-79’ & 98 & 76 & 53 & 45 & 76 \\
\hline 'OR-55' & 32 & 49 & 28 & 55 & 67 \\
\hline WGV & 90 & 74 & 58 & 69 & 97 \\
\hline
\end{tabular}

Table 6. The biochemical characterization of the British varieties, introduced into the in vitro collection

\begin{tabular}{|c|c|c|c|c|c|c|}
\hline \multirow{2}{*}{ Indices } & \multicolumn{2}{|c|}{ Northern Brewer } & \multicolumn{2}{|c|}{ WGV } & \multicolumn{2}{|c|}{ East Kent Holding } \\
\hline & Sample & Passport data & Sample & Passport data & Sample & Passport data \\
\hline Alpha-acids, $\%$ & 10.7 & $6.0-10.0$ & 6.5 & $4-7$ & 5.4 & $4.5-6.5$ \\
\hline Beta-acids, $\%$ & 4.8 & $3.0-5.0$ & 4.1 & $1.9-2.8$ & 2.2 & $1.9-2.8$ \\
\hline Ratio of $\beta / \mathrm{a}$ & 0.47 & $1.2-3.3$ & 0.61 & $4.8-6.5$ & 0.41 & $0.42-0.56$ \\
\hline Total content of oil (ml/100 g) & 2.5 & $1.2-1.4$ & 1.6 & $1.3-1.7$ & 0.7 & $0.4-0.8$ \\
\hline Myrcene, $\%$ & 32.2 & $45-55$ & 20.6 & 25 & 30.4 & $\mathrm{n} / \mathrm{a}$ \\
\hline Farnesene, $\%$ & - & - & 7.9 & $6.8-8.7$ & - & - \\
\hline \multirow[t]{2}{*}{ Humulene, \% } & 19.7 & $17-22$ & 23.2 & $21-28$ & 39.6 & $38-44$ \\
\hline & \multicolumn{2}{|c|}{ OZ-79 } & \multicolumn{2}{|c|}{ Target } & \multicolumn{2}{|c|}{ OR-55 } \\
\hline Alpha-acids, $\%$ & 8.0 & $6.4-8.8$ & 7.0 & $8-13$ & 7.6 & $7.0-9.0$ \\
\hline Beta-acids, $\%$ & 4.6 & $3.2-4.6$ & 3.3 & $4.3-5.7$ & 5.4 & $4.5-5.2$ \\
\hline Ratio of $\beta / \mathrm{a}$ & 0.56 & $0.5-0.6$ & 0.47 & $0.45-0.72$ & 0.74 & $0.55-0.8$ \\
\hline Total content of oil (ml/100 g) & 1.6 & $1.5-2.4$ & 0.8 & $0.7-1.3$ & 2.6 & $2.0-3.5$ \\
\hline Myrcene, $\%$ & 35.8 & $22-39$ & 25.4 & $45-55$ & 30.9 & $26-41$ \\
\hline Farnesene, \% & - & - & - & - & - & - \\
\hline Humulene, \% & 1.4 & $0.8-2.4$ & 0.11 & $9-10$ & 3.0 & $2.2-4.0$ \\
\hline
\end{tabular}

The mutations may also occur due to sub- and supraoptimal doses of growth hormones, used in the culture media (Vidal M and De Garcià E, 2000) The incidence of somaclonal variability may increase with larger passages and their duration (Bairu $M$ et al, 2006), fast growth of the culture may promote the occurrence of somaclonal mutations (Petolino J et al, 2003). In our studies, long-term maintenance of a donor plant in the in vitro collection with constant passaging, the use of stimulants and other chemical preparations may also initiate somaclonal variability.

The first control of genome stability and genetic identity of explants from donor plants of hop varieties during their maintenance in the in vitro collection for two years demonstrated that this period is insufficient for the final conclusion. Therefore, genome stability of the varieties, introduced to the in vitro collection, requires further studies.

\section{CONCLUSIONS}

The foundations of creating and maintaining the in vitro collection of hop varieties in Ukraine were first developed using the results of perennial research on cultivating hop planting material on the MurashigeSkoog nutrient medium. It allows decreasing the concentration of nutrients in the culture medium by $50 \%$, replacing expensive gel-forming preparation for the maintenance of plants in the culture medium - agaragar, the share of whose cost in the medium composi- 
tion is up to $70 \%$, with a cheaper substance - modified starch DDKamod or agroperlite, and reducing the expenses for the maintenance of genetic pool in the in vitro collection.

It was determined that the spectra of microsatellite loci of the amplified DNA of the explants, cultivated in vitro for three years did not differ from the spectra of plant DNA prior to cloning, which demonstrates DNA stability and allows to cultivate hop varieties in the in vitro culture without any changes in the genome during this period.

The composition of media for cultivation of seven British hop varieties in in vitro conditions was selected. The results of the studies serve as a basis for replenishing the in vitro gene bank of the Institute of Agriculture of Polissia, NAAS, and using it in the selection process. At present the in vitro gene bank has over 40 hop varieties from Great Britain, the USA, Germany, Czech Republic, Slovenia and other countries.

\section{Розширення та підтримання колекції національних та іноземних сортів хмелю in vitro в Україні}

В. Б. Ковальов ${ }^{1, *}$, Т. І. Козлик ${ }^{2}$, Л. В. Проценко ${ }^{3}$, А. В. Бобер ${ }^{4}$, Б. Ф. Кормільцев ${ }^{5}$

${ }^{1}$ Житомирський національний агроекологічний університет,

Житомир, бульвар Старий, 7, Україна, 10008

2, 3,4 Інститут сільського господарства Полісся НААН, шосе Київське, 131, Житомир, Україна, 10007

${ }^{5}$ Національний університет біоресурсів і природокористування України, вул. Героїв оборони, 15, Київ, Україна, 03041

E-mail: k82_super@ukr.net 1,*, kozlyk-tanya@ukr.net ${ }^{2}$, Lidiya.procenko@ukr.net ${ }^{3}$, bober_1980@i.ua ${ }^{4}$, borfed50@ukr.net ${ }^{5}$

Незважаючи на занепад виробництва хмелю в Україні, частина його продукції, створена на основі українських ароматичних сортів, високо цінується на міжнародному ринку i експортується до інших країн. Таким чином, розширення асортименту національного хмелевиробництва є важливою передумовою для досягнення достатнього рівня його конкурентоспроможності. Задоволення цієї потреби змушує виробників створювати сорти 3 унікальними характеристиками, що вимагає пошуку нових форм і різновидів хмелю 3 підвищеним вмістом різних біологічно активних речовин у шишках. У зв'язку з цим, у статті обговорюється національна дослідницька програма, спрямована на вивчення генетичної стабільності сортів хмелю під час багаторазового пасажування та зберігання експлантів в умовах in vitro, введення їх до колекції, уточнення складу поживного середовища Мурасіго-Скуга для окремих сортів. Було проведено аналіз рослин за морфологічними та сортовими ознаками, ідентифікацію сортів за біохімічними критеріями, оздоровлення регенерантів хмелю за допомогою імуноферментного аналізу (ІФА), використано молекулярно-генетичний метод на основі ПЛР-аналізу для ідентифікації генотипів хмелю та визначення генетичної стабільності, а також удосконалення методу мікроклонального розмноження хмелю. Вперше в Україні за результатами багаторічних досліджень вирощування садивного матеріалу хмелю за допомогою комплексу поживних речовин МурасігоСкуга було розроблено основи створення та підтримання колекції in vitro сортів хмелю, що дозволяє знизити концентрацію поживних речовин у поживному середовищі на $50 \%$, замінити дороговартісний гелеутворюючий препарат для підтримки рослин у поживному середовищі - агар-агар, частка вартості якого у складі середовища досягала до 70 \%, дешевшим препаратом модифікованим крохмалем ДДКамод або агроперлітом, i зменшити витрати на утримання генетичного фонду в колекції in vitro. Було встановлено, що спектри мікросателітних локусів ампліфікованої ДНК експлантів, культивованих in vitro, протягом періоду дослідження не відрізнялися від спектрів ДНК рослин до клонування, що продемонструвало стабільність ДНК та дозволило культивувати сорти хмелю в культурі in vitro без змін геному. Було підібрано склад середовищ для культивування та довготривалого зберігання сортів хмелю в умовах in vitro.

Ключові слова: хміль, сорти, ідентифікація, генотипи, колекція in vitro, поживне середовище.

\section{REFERENCES}

Adams AN. (1975) Elimination of viruses of hop (Humulus lupulus L.) by heat therapy and meristem culture. J Hort Sci. 58:151-60. doi: 10.1080/00221589.1975.11514616.

Bairu MW, Fennell CW, Van Staden J. (2006) The effect of plant growth regulators on somaclonal variation in Cavendish banana. Scientia Horticulturae. 108:347-351. doi: 10.1016/j.scienta.2006.01.039.

Beatson RA, Alspach PA, Stephens MJ, Buck EJ, Datson PM, Ferguson AR. (2016) Breeding polyploid hop cultivars for New Zealand conditions. Acta Hortic. 1127: 9-14. doi: 10.17660/Acta Hortic.2016.1127.2.

Bilinska OV. (2009) Influence of gel-forming and lower carbohydrate components of nutrient medium on the induction of haploid barley in culture of pollen in vitro. Scientific Bulletin of the National Agrarian University. Series Biology. 1:91-98. (in Ukrainian).

Brady JL, Scott NS, Thomas MR. (1996) DNA typing of hops (Humulus lupulus L.) through application of RAPD and microsatellite marker sequences converted to sequence tagged sites (STS). Euphytica. 91:277-284. doi: 10.1007/ BF00033088. 
Cerenak A, Jakse J, Javornik B. (2004) Identification and Differentiation of Hop Varieties Using Simple Sequence Repeat Markers. J Amer Soc Brew Chem. 62(1): 1-7. doi: 10.1094/ASBCJ-62-0001.

Debergh PC, Read PE. (1990) Micropropagation. In: Micropropagation, technology and application. London: Kluwer Academic. p 1-13.

Dresel M, Vogt C, Dunkel A, Hofmann T. (2016) The bitter chemodiversity of hops (Humulus lupulus L.). J Agric Food Chem. 64: 7789-7799. doi: 10.1021/acs.jafc.6b03933.

Gergerich RC, Welliver RA,Osterbauer NK, Kamenidou $S$, Martin RR, Golino DA, Eastwell K, Fuchs M, Vidalakis $G$, Tzanetakis IE. (2015) Safeguarding Fruit Crops in the Age of Agricultural Globalization. Plant Disease. 99(2):176-87. doi: 10.1094/PDIS-07-14-0762-FE.

Hataya T, Arimoto R, Suda N, Uyeda I. (2001) Molecular characterization of Hop mosaic virus: its serological and molecular relationships to Hop latent virus. Arch Virol. 146:1935-48. doi: 10.1007/s007050170043.

Henning JA, Coggins J, Peterson M. (2015) Simple SNPbased minimal marker genotyping for Humulus lupulus L. identification and variety validation. BMC Res Notes. 8:542. doi: 10.1186/s13104-015-1492-2.

Jakse J, Kindlhofer K, Javornik B. (2004) Assessment of genetic variation and differentiation of hop genotypes by microsatellite and AFLP markers. Centre for Plant Biotechnol Breedg. 44(5):773-782. doi: 10.1139/gen44-5-773.

Kalinin FL., Sarnatskaya VV, Polischuk VE. (1980) Methods of culture of tissues in the physiology and biochemistry of cultivated plants. Kiev: Scientific thought. 488 p. (in Ukrainian).

Kormiltsev BF, Badamshina LP, Levchuk MG. (2010) Patent No. 92168. 2010. Ukraine. IPC (2009) A01H4 / $00 \mathrm{C} 12 \mathrm{~N} 5 / 04$. Method of microclonal reproduction of hunted regenerants grown from apexes in vitro. Applicant and patent holder - Institute of Agriculture of Polissia; Application dated October 25, 2007; published June 10, 2008, Bull N 11:5 p.

Kovalev VB, Kormiltsev BF, Shtanko IP, Chernenko OV. (2015) Molecular genetic identification of common hops (Humulus lupulus L.) for use of SSR markers: method. recommendations Zhitomir: Polissia Institute of Agriculture, Nat Acad Sci Ukraine. 20 p. (in Ukrainian).

Kozlyk TI, Kormiltsev BF, Kovalev VB. (2017) Introduction and cultivation of British hop varieties into the in vitro collection. Ahropromyslove vyrobnytstvo Polissia. (10):73-76.

Kunitake H, Koreeda K, Mii M. (1995) Morphological and cytological characteristics of protoplast-derived plants of statice (Limonium perezii Hubbard). Scientia Horticulturae. 60:305-312. doi: 10.1016/0304-4238(94)00713-P.
Liberatore CM, Mattion G, Rodolfi M, Ganino T, Fabbri A, Chiancone B. (2018) Chemical and physical pretreatments to improve in vitro seed germination of Humulus lupulus L., cv. Columbus. Sci Horticulturae. 235:86-94. doi: 10.1016/j.scienta.2018.02.077.

Melnichuk MD, Klyuddenko AA, Davydenko OA. (2000) Obtaining non-virus hop planting material (Humulus lupulus L.) in vitro. Scientific herald of NAU. 29:47-52. (in Ukrainian).

Melnichuk M. D, Overcherko VV, Spiridonov VG, Parry $M F$. (2008) DNA identification of common honeybee genotypes (Humulus lupulus L.) based on SSR markers: method. recommendations. Kyiv: Publishing Center of NAU. 24p. (in Ukrainian).

Patzak J, Henychova A. (2008) Evaluation of Genetic Variability within Actual Hop (Humulus lupulus L.) Cultivars by an Enlarged Set of Molecular Markers. Czech J Genet Plant Breed. 54(2):86-91. doi: 10.17221/ 175/2016-CJGPB.

Petolino JF, Roberts JL, Jayakumar P. (2003) Plant cell culture: a critical tool for agricultural biotechnology. In: Handbook of industrial cell culture: mammalian, microbial and plant cells. New Jersey. Humana Press. p 243-258. doi: 10.1385/1-59259-346-1:243.

Protsenko L, Litvynchuk S. (2015) Competitiveness of Ukrainian pellet hops production. Ukr J Food Sci. 3(1):51-59.

Sivolap YuM, Zakharova O, Kozhukhova NE, Ignatova SO, Pristavsky MS, Zelenina GA. (2010) Modern biotechnology is useful in the estimation of the genetic diversity of Ukrainian varieties of hop (Humulus Lupulus L.). Cytol Genet 44(5):263-271. doi: 10.3103/S0095 452710050014.

Spiegel S, Stein A, Tam Y. (1995) In vitro thermotherapy of Rosaceous fruit trees. Acta Horticulturae. 386:419-420. doi: 10.17660/ActaHortic.1995.386.57.

Shtanko IP, Kovalev VB, Kormiltsev BF. (2016) Results of studying the genome of hop varieties under long-term cultivation, by collection Ahropromyslove vyrobnytstvo Polissia. (6):61-65.

Stajner N, Satovic Z, Cerenak A, Javornik B. (2008) Genetic structure and differentiation in hop (Humulus lupulus L.) as inferred from microsatellites. Euphytica. 161:301311. doi: 10.1007/s10681-007-9429-z.

Trojak-Goluch A, Kawka M, Czarnecka D. (2015) The effects of explant source and hormone content on plant regeneration and induction of tetraploids in Humulus lupulus L. in vitro cellular \& developmental biologyplant. 51(2):152-159. doi: 10.1007/s11627-014-9661-x.

Vidal ME, De Garcià E. (2000) Analysis of a Musa spp. somaclonal variant resistant to yellow sigatoka. Plant Mol. Biol. Rep. 18:23-31. doi: 10.1007/BF0282529030. 